measurement with the Folin phenol reagent. J. Biol. Chem., 193: 265 (1951).

20. Mahadevan, S., and Tappell, A. L.: Lysosomal lipases of rat liver and kidney. J. Biol. Chem., 243: 2849 (1968).

21. Mann, J. T., III, and Tove, S. B.: Purification and properties of a lipase from rat adipose tissue. J. Biol. Chem., 24l: 3595 (1966).

22. Nyberg, G., Mellgren, G., and Smith, U.: Human adipose tissue in culture VI. Effect of age on cell size and lipolysis. Acta Paediat. Scand., 65: 313 (1976)

23. Okuda, H., Yanagi, I., Sek, F. J., and Fujii, S.: Studies on the hormone sensitive lipase of rat epididymal adipose tissue. J. Biochem., 68: 199 (1970).

24. Poznanski, W. J., Waheed, I., and Van, R.: Human fat cell precursors Morphologic and metabolic differentiation in culture. Lab. Invest., 29: 570 (1973).

25. Puck, T. T., Ciecuira, S. J., and Fisher, H. W.: Clonal growth in vitro of human cells with fibroblasts morphology: Comparison of grnwth and general characteristics of single epithelioid and fibroblast-like cells from a variety of human organs. J. Exp. Med., 101: 148 (1959).

26. Redding, T. W., and Schally, A. V.: Effect of hypothalamic preparations on human omental adipose tissue in vitro. Metabolism, 21: 499 (1972).

27. Rizack, M. A.: An epinephrine-sensitive lipolytic activity in adipose tissue. J. Biol. Chem., 236: 657 (1961).

28. Robinson, D. S.: The clearing factor lipase activity of adipose tissue. In: Handbook of Physiology, Section 5, Adipose Tissue, p. 295 (The Williams \& Wilkins Co., Baltimore, 1965).

29. Schnatz, J. D.: Neutral and alkaline lipolytic activities in human adipose tissue. Biochim. Biophys. Acta, 116: 243 (1966).

Copyright $(1) 1978$ International Pediatric Research Foundation, Inc

$0031-3998 / 78 / 0012-0001 \$ 02.00 / 0$
30. Schnatz, J. D., Shepard, C., and Williams, R.: The hydrolysis of tissue triglyceride emulsions by homogenates of normal, adrenalin-stimulated and insulin deficient rat epididymal adipose tissue. Metabolism, 14: 122 (1965).

31. Schwartz, J. P., and Jungas, R. L., Studies on the hormone sensitive lipase of adipose tissue. J. Lipid Res., 12: 553 (1971)

32. Stoffel, W., and Greten, H.: Studies on lipolytic activities of rat liver lysosomes. Hoppe Seyler's Z. Physiol. Chem., 348: 1145 (1967).

33. Strand, O., Vaughn, M., and Steinberg, D.: Rat adipose tissue lipases: Hormone sensitive lipase activity against triglycerides compared with activity against lower triglycerides. J. Lipid Res., 5: 554 (1964).

34. Van, R. L. R., Bayliss, C. E., and Roncari, A. K.: Cytological and enzymological characterization of adult human adipocyte precursors in culture. J. Clin. Invest., 58: 699 (1976).

35. Flow Laboratories, Rockville, MD 20852.

36. American Instrument Co., Silver Spring, MD 20910

37. Research Products Int., Elk Grove Village, IL 60005.

38. We thank Ms. Joanne Werntz for valuable technical assistance and Drs. William Mellman and Alfred $M$. Bongiovanni for reviewing the manuscript. We also thank the surgeons and the operating room nursing staff of the Children's Hospital of Philadelphia for their cooperation in obtaining the adipose tissue specimens.

39. This work was supported by General Research Support Grant GRS 5-S-01RR05506-13, NIH, and Human Genetic Center Grant GM-20138.

40. Requests for reprints should be addressed to: Paul M. Coates, M.D. The Children's Hospital of Philadelphia, 34th and Civic Center Boulevard, Philadelphia, Pennsylvania 19104 (USA).

41. Received for publication December 13,1976.

42. Accepted for publication April 26, 1977.

Printed in U.S.A.

Pediat. Res. 12: 29-34 (1978)

Lead

metabolic balance studies

\title{
Absorption and Retention of Lead by Infants
}

\author{
EKHARD E. ZIEGLER, ${ }^{(21)}$ BARBARA B. EDWARDS, ROBERT L. JENSEN, KATHRYN R. \\ MAHAFFEY, AND SAMUEL J. FOMON \\ Department of Pediatrics, University of lowa, lowa City, Iowa, USA
}

\section{Summary}

Eighty-nine metabolic balance studies were performed with 12 normal infants ranging in age from 14-746 days. Intake and fecal and urinary excretions of lead were determined and net absorption and net retention were calculated. Subjects were fed milk or formula and commercially prepared strained foods. Intakes of lead ranged from $0.83-22.61 \mu \mathrm{g} / \mathrm{kg} /$ day with a mean of $9.43 \mu \mathrm{g} / \mathrm{kg} /$ day. Urinary excretion averaged 1.02 (SD 0.68) $\mu \mathrm{g} / \mathrm{kg} /$ day and was positively correlated with lead intake (Fig. 1). Fecal excretion was highly correlated with intake of lead (Fig. 2); fecal excretion exceeded intake in 10 studies. In 61 balance studies with lead intakes greater than $5 \mu \mathrm{g} / \mathrm{kg} / \mathrm{day}$, net absorption averaged $41.5 \%$ of lead intake and net retention averaged $31.7 \%$ of intake.

Retention of lead was highly correlated with lead intake (Fig. 3). Urinary plus fecal excretion of lead exceeded intake in 19 of 28 balances in which lead intakes were less than $5 \mu \mathrm{g} / \mathrm{kg} / \mathrm{day}$. Absorption and retention of lead were inversely correlated with intake of calcium (Fig. 4). Absorption and retention of lead accounted for greater percentages of intake of lead in this study of infants and young children than have been reported in studies of older subjects.

\section{Speculation}

Highly efficient absorption and retention of ingested lead by young children may be partly responsible for the high prevalence of lead intoxication in this age group.

In 1971 an ad hoc committee of the Bureau of Community Environmental Management, PHS (9) suggested $300 \mu \mathrm{g} /$ day for children as the daily permissible intake of lead from all sources. Children 1-3 years of age were specifically included. The daily permissible intake was based, in part, on the assumption that $90 \%$ of ingested lead would be excreted - an assumption based on extrapolation from data concerning adults.

However, it is known that suckling rats absorb a greater percentage of ingested lead than do older rats $(6,10)$. In addition, Alexander et al. (1) have reported data from 11 metabolic balance studies with subjects less than 8 years of age, including six studies with three subjects less than 2 years of age. As estimated from the figures included in the publication, these studies indicated that considerably less than $90 \%$ of ingested lead was excreted. 
The present study was undertaken to establish the extent of absorption and retention of lead by infants and young children under circumstances in which lead ingested with food constituted the major source of lead exposure. The metabolic balance technique was utilized to determine intake, urinary excretion, and fecal excretion of lead. From these measurements, net absorption and net retention were calculated. Lead intakes similar to those supposedly occurring under ordinary circumstances were achieved by feeding milk or formula and other foods (beikost). No lead was added to foods nor were any special diets used.

\section{MATERIALS AND METHODS}

\section{STUDY DESIGN}

The metabolic balance studies were $72 \mathrm{hr}$ in duration, usually with 11 days between the last day of one balance study and the first day of the next. In a few instances, more than 18 days elapsed between studies. When the diet was altered to provide a new level of lead intake, an adjustment period of no less than 11 days was interposed.

In the case of foods provided by us, the mother was asked to save all empty or partially empty containers and these were collected from the family at the time of the next delivery. The returned containers were weighed to determine the quantity of food consumed.

Two separate studies were conducted. These differed slightly in experimental design and in the extent of control of lead intake between balance studies. In study 1 , three to eight balance studies were performed with each of nine infants. Lead intake varied among infants, but in the case of a specific infant intake was maintained at the same level for all balance studies or changed no more than once. Between balance studies choices of commercially prepared strained foods by older infants (over 6 months of age) were not controlled except during the 3 days immediately preceding a study. Differences in lead intakes from one subject to another, or in some cases in the same subject at different times, resulted primarily from differences in lead content of various commercially prepared fruits and juices.

In study 2 , each of six infants (three infants had also participated in study 1) consumed, in randomized order, diets providing low, intermediate, and moderate intakes of lead. These diets were consumed during and also between balance studies. At each level of lead intake, two balance studies (three balance studies at low intake in one infant and at moderate intake in another) were performed consecutively.

The following target levels of lead intake were set: low, 30$40 \mu \mathrm{g} /$ day; intermediate, $70-80 \mu \mathrm{g} /$ day; and moderate, $120-$ $130 \mu \mathrm{g} /$ day. To achieve these intakes a number of food items in addition to milk or formula were selected according to both lead content and anticipated acceptance by the infant. These were supplied to the family. No other foods were to be fed.

\section{SUBJECTS}

Twelve infants and young children (six males and six females) were studied between July 1974 and December 1975. In most cases the parents were students or faculty of the University of Iowa. Ages of the subjects at the time of study ranged from 14746 days (Appendix). All subjects were in good health and demonstrated rates of gain in weight and length above the 10th percentile of the selected reference data $(4)$. The study was explained in detail to one or both parents by one of us (B.B.E.) and written consent was obtained.

\section{PROCEDURES}

Subjects were admitted to the Pediatric Metabolic Unit for performance of the metabolic balance studies. Concentrations of lead and of various nutrients in milk, formula, and beikost were determined. The quantity of each food consumed was recorded. From lead concentrations of the foods and the weights of foods consumed, intakes of lead were calculated. Urine and feces were collected using previously described techniques (5). Air was sampled (22 liters/min for $60 \mathrm{~min}$ ) in the Pediatric Metabolic Unit and in the homes of six subjects using standard equipment and procedures (13). In each instance, lead content was less than $0.2 \mu \mathrm{g} / \mathrm{m}^{3}$ of air.

Efforts were made to avoid contamination in collecting and handling of speciments of urine and feces. Collection vessels and storage flasks of borosilicate glass were washed with leadfree nitric acid $(20 \% \mathrm{v} / \mathrm{v})$ and rinsed thoroughly with glassdistilled water. Urine specimens were transferred at frequent intervals to the flasks, which were kept covered with plastic wrapping and stored in a refrigerator during the collection period.

Determinations of lead concentration were carried out in duplicate or triplicate with samples of food and feces and with some but not all samples of urine. Samples of food, feces, and dust were dried at $100^{\circ}$ and dry-ashed at $400^{\circ}$ overnight. The ash was dissolved in $1 \mathrm{~N}$ nitric acid. Urine samples were brought to $\mathrm{pH} 2.8$ by adding nitric acid. Standard solutions containing $0.2,0.4$, and $0.6 \mathrm{ppm}$ lead (as the nitrate) were prepared with $0.01 \mathrm{~N}$ nitric acid from stock standard solution containing lead in a concentration of $1 \mathrm{~g} /$ liter. Samples (i.e., dissolved ashes or acidified urine), standards, and distilled water blanks $(50 \mathrm{ml}$ each) were subjected to solvent extraction using $5.0 \mathrm{ml}$ freshly prepared $2 \%(\mathrm{w} / \mathrm{v})$ aqueous ammonium pyrrolidine dithiocarbamate and $5.0 \mathrm{ml}$ methylisobutyl ketone (3). Lead concentration was determined using a Perkin-Elmer model 303 atomic absorption spectrophotometer. All chemicals were reagent grade and contained less than $10 \mathrm{ppb}$ lead by analysis.

Seven samples of formula and three samples of whole cow milk were analyzed in duplicate. Mean concentrations of lead were $18 \mu \mathrm{g} / \mathrm{kg}$ (range 15-20) in formula and $10 \mu \mathrm{g} / \mathrm{kg}$ (range $7-15)$ in milk. Fifty-six duplicate samples of beikost were analyzed. The technical error was $4.70 \mu \mathrm{g} / \mathrm{kg}$ (coefficient of variation $9.1 \%$ ). In 25 instances the difference in lead concentration between duplicates was $3 \mu \mathrm{g}$ or less per $\mathrm{kg}$ of food. In 89 duplicate determinations of fecal lead content the technical error was $27.0 \mu \mathrm{g} / \mathrm{kg}$ (coefficient of variation $5.9 \%$ ). In 17 duplicate determinations of urinary lead content the technical error was $2.22 \mu \mathrm{g} /$ liter (coefficient of variation 13.8\%).

Recoveries of lead added to foods, feces, and urine averaged $98.2 \%$ (SD $8.0 \%$ ) for 50 foods; $99.9 \%$ (SD 9.5\%) for 60 fecal samples, and $101.0 \%$ (SD $4.7 \%$ ) for 10 urine samples.

\section{DIET}

Milk and Formula. Milk or formula was supplied to the family. During 12 balance studies two younger infants (subjects 2159 and 2179) were fed a soy isolate-based formula, supplied in ready-to-feed 8-oz glass bottles (Ross Laboratories, Colombus, $\mathrm{OH})$. The formula was similar to the commercially available formula, Isomil, except that the carbohydrate was entirely maltodextrin rather than a mixture of maltodextrin and sucrose. The concentration of iron (from ferrous sulfate) was $20 \mathrm{mg} / \mathrm{liter}$ and that of added vitamin D was $400 \mathrm{IU} /$ liter. The other infants were fed whole cow milk containing 400 IU vitamin $D / l i t e r$ supplied in quart cans (Ross Laboratories). An iron supplement ( $7.5 \mathrm{mg}$ iron from ferrous sulfate) was added to each quart can of milk before feeding.

Beikost. Commercially prepared foods other than milk and formula were purchased by the family or provided by us. Nine different infant fruit juices were used. In study 1 some of the juices contained relatively high lead concentrations (145-327 $\mu \mathrm{g} / \mathrm{kg})$. These were excluded in study 2 and lead concentration of juices then ranged from $23-55 \mu \mathrm{g} / \mathrm{kg}$. Five varieties of strained fruits with lead concentrations from $13-131 \mu \mathrm{g} / \mathrm{kg}$ and seven varieties of strained vegetables with lead concentrations ranging from $\cdot 14-73 \mu \mathrm{g} / \mathrm{kg}$ were used (17). 


\section{RESULTS}

Results of the two series of balance studies are presented separately in Tables 1 and 2 and in combined form in Figures 1-3. Data from individual balance studies are presented in the Appendix.

\section{STUDY 1}

Data from 51 balance studies performed in study 1 are summarized in Table 1. As may be seen from Figure 1, urinary excretion of lead demonstrated only a modest increase with increasing intake of lead. The quantities of lead excreted in the urine were low in relation to those excreted in feces (Table 1). Fecal excretion of lead, on the other hand, was strongly correlated with intake (Fig. 2). Fecal excretion exceeded intake of lead in five balance studies. Retention of lead increased with increasing intake (Fig. 3).

\section{STUDY 2}

Because target levels of lead intake were applied irrespective of body weight, there was some overlap in the range of values of lead intake expressed per $\mathrm{kg}$ body weight at the intermediate and moderate intake levels (Table 2). As in study 1 , the range of urinary excretions of lead was relatively small when compared with the wide range of intakes (Fig. 1). Fecal excretion of lead increased with increasing intake (Fig. 2). At low intakes of lead fecal excretion exceeded intake in four studies and mean values

Table 1. Summary of 51 lead balance studies performed in nine subjects (study 1)

\begin{tabular}{lrcc}
\hline & Mean & SD & \multicolumn{1}{c}{ Range } \\
\hline Age (days) & \multicolumn{1}{c}{248} & & $14-746$ \\
Intake $(\mu \mathrm{g} / \mathrm{kg} /$ day $)$ & 10.29 & 5.46 & $1.72-22.61$ \\
Urinary excretion $(\mu \mathrm{g} / \mathrm{kg} /$ day $)$ & 1.04 & 0.82 & $0.07-5.90^{1}$ \\
& $(0.94$ & 0.45 & $0.07-1.92)$ \\
Fecal excretion $(\mu \mathrm{g} / \mathrm{kg} /$ day $)$ & 5.90 & 3.65 & $0.62-14.75$ \\
Absorption $(\mu \mathrm{g} / \mathrm{kg} /$ day $)$ & 4.39 & 3.91 & $-3.12-12.43$ \\
Retention $(\mu \mathrm{g} / \mathrm{kg} /$ day $)$ & 3.35 & 3.62 & $-3.82-11.29$ \\
\hline
\end{tabular}

${ }^{1}$ High value of 5.90 is more than 3 times higher than next lowest ralue and therefore may represent analytic error or contamination. Exclusion of this value yields mean, $\mathrm{SD}$, and range given in parentheses in lower line.

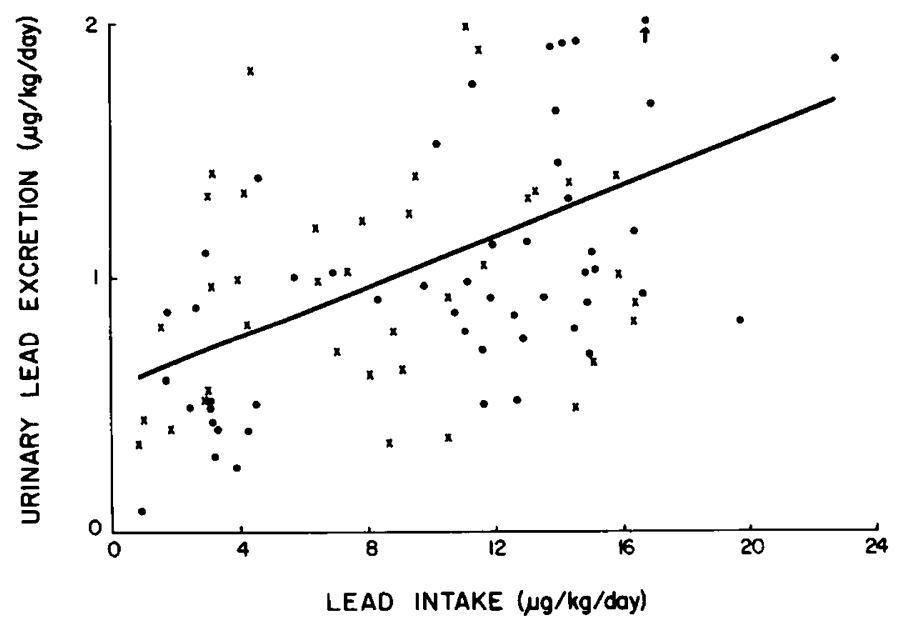

Fig. 1. Urinary excretion of lead in relation to lead intake. Each dot refers to the result of one metabolic balance in study 1 and each $x$ refers to the result of one metabolic balance in study 2 . In one metabolic balance (arrow) urinary excretion was $5.90 \mu \mathrm{g} / \mathrm{kg} / \mathrm{day}$. The calculated regression $(y=0.0493 x+0.554 ; r=0.381)$ is included.

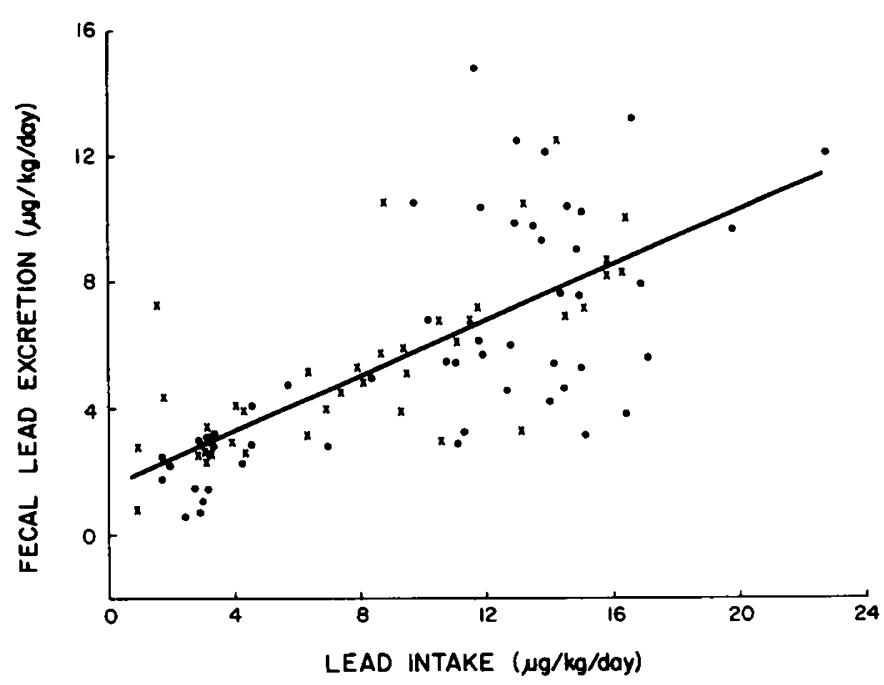

Fig. 2. Fecal excretion of lead in relation to lead intake. Symbols are as in Figure 1. The calculated regression $(y=0.443 x+1.545 ; r=$ 0.710 ) is included.

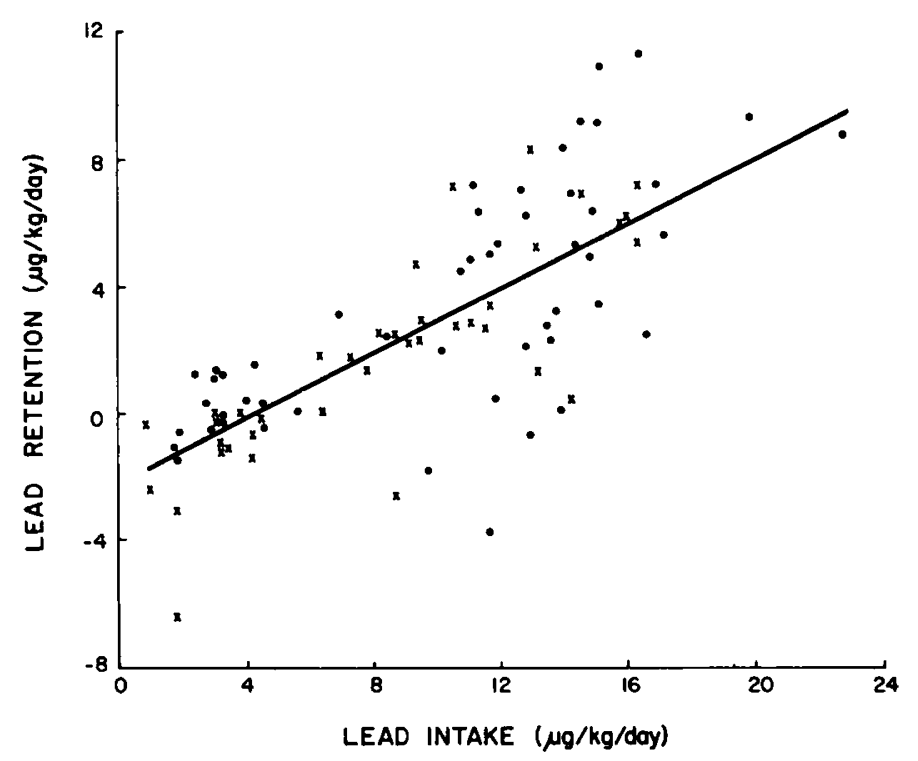

Fig. 3. Lead retention in relation to lead intake. Symbols as in Figure 1. The calculated regression $(y=0.509 x-2.110 ; r=0.755)$ is included.

for net absorption and net retention were negative. At intermediate and moderate intakes of lead, net absorption and net retention were positive in all but one of the balance studies.

\section{COMBINED DATA}

Lead Intake. For all 89 balance studies intake of lead averaged $9.44 \mu \mathrm{g} / \mathrm{kg} /$ day (SD 5.27, range $0.83-22.61$ ). Because it seemed possible that the diets consumed immediately before a balance study might have a carry-over effect on the balance study, an attempt was made to control lead intake during at least the 3-day period preceding each balance study. Intake of lead during the 3-day prebalance periods averaged $8.44 \mu \mathrm{g} / \mathrm{kg} /$ day (SD 5.55). Thus, prebalance intake of lead averaged 1.01 $\mu \mathrm{g} / \mathrm{kg} /$ day (SD 3.35) less than intake during balance studies.

Urinary Lead Excretion. Mean urinary excretion was 1.02 $\mu \mathrm{g} / \mathrm{kg} /$ day (SD 0.68 , range $0.07-1.98$ with the exception of one value of 5.90). Urinary excretion increased with increasing intake $(r=0.381 ; P<0.001)$ (Fig. 1). Urinary excretion accounted only for a small portion of total excretion. There was no significant change in urinary excretion with age. 
Fecal Excretion and Absorption of Lead. The correlation between fecal excretion and intake of lead was significant $(r=$ $0.710 ; P<0.001$ ) (Fig. 2). It should be noted that fecal excretion of lead exceeded intake in 7 of 28 studies with lead intakes less than $5 \mu \mathrm{g} / \mathrm{kg} /$ day and in only 3 of 61 studies at higher intakes.

Net absorption of lead (micrograms per kg per day), calculated as intake minus fecal excretion, was correlated with intake of lead $(r=0.786 ; P<0.001)$. Expressed as percentage of intake, absorption averaged $26.2 \%$ and was correlated $(r=$ $0.431 ; P<0.001$ ) with lead intake. Because extremely low dietary intakes of lead are difficult to achieve except under experimental conditions, we have arbitrarily divided balance studies into those with intakes below and those with intakes above $5 \mu \mathrm{g} / \mathrm{kg} /$ day. Mean absorption in 28 balance studies with lead intakes below $5 \mu \mathrm{g} / \mathrm{kg} / \mathrm{day}$ was $0.24 \mu \mathrm{g} / \mathrm{kg} / \mathrm{day}$. In 61 balance studies (10 subjects) with lead intakes above $5 \mu \mathrm{g} / \mathrm{kg} /$ day, mean absorption was $5.31 \mu \mathrm{g} / \mathrm{kg} /$ day, representing $41.5 \%$ of lead intake.

Retention. Mean retention was $2.69 \mu \mathrm{g} / \mathrm{kg} /$ day (SD 3.56), equivalent to $11.3 \%$ of intake. The relationship between intake and retention of lead was highly significant whether expressed in micrograms per $\mathrm{kg}$ per day $(r=0.755 ; P<0.001)$ (Fig. 3) or as percentage of intake $(r=0.507 ; P<0.001)$. Retention was negative (i.e., total excretion exceeded intake) in 23 studies, of which 19 occurred at intakes below $5 \mu \mathrm{g} / \mathrm{kg} / \mathrm{day}$ and 4 occurred at higher intakes. With intakes of lead greater than 5 $\mu \mathrm{g} / \mathrm{kg} /$ day, mean retention was $4.16 \mu \mathrm{g} / \mathrm{kg} /$ day, equivalent to $31.7 \%$ of intake. With intakes less than $5 \mu \mathrm{g} / \mathrm{kg} /$ day, mean retention was $-0.48 \mu \mathrm{g} / \mathrm{kg} /$ day, equivalent to $-33.1 \%$ of intake.
Retention, whether expressed in absolute terms or as percentage of intake, did not change with age. Regressions of lead retention on lead intake (micrograms per $\mathrm{kg}$ ) were calculated for individual subjects who had had four or more balance studies. These subject-specific regressions were homogeneous with respect to slope and intercept. Thus, the study did not provide evidence of a significant difference between individual infants in the relation of lead intake to lead retention.

Calcium Intake and Lead Balance. Calcium intake and lead intake were not significantly correlated. A significant inverse relationship was demonstrated between calcium intake and absorption of lead expressed either as micrograms per $\mathrm{kg}$ per day $(r=-0.240 ; P<0.05)$ or as percentage of intake $(r=$ $-0.277 ; P<0.01)$. Similarly, calcium intake was inversely correlated with retention of lead expressed as micrograms per kg per day $(r=-0.279 ; P<0.01)$ or as percentage of intake (Fig. 4) $(r=-0.284 ; P<0.01)$.

\section{DISCUSSION}

Animal studies have indicated that younger animals absorb and retain a greater percentage of ingested lead than do older animals. Kostial et al. (10) fed $2 \mu \mathrm{Ci}{ }^{203} \mathrm{~Pb}$ contained in a formula based on cow milk to 5-day to 7-day-old rats. After 80 $\mathrm{hr}, 53.4 \%$ of the administered dose was retained in the carcass (excluding the gastrointestinal tract). They stated that similar studies of adult rats demonstrated only $1 \%$ retention. Forbes and Reina (6) measured the activity of ${ }^{212} \mathrm{~Pb}$ in the gastrointestinal tract after administration (by gavage) of a dose of the radioactive material. The loss of ${ }^{212} \mathrm{~Pb}$ in feces was not determined. The activity of ${ }^{212} \mathrm{~Pb}$ in the contents of the gastrointes-

Table 2. Summary of 33 lead balance studies in six subjects studied at each of three different lead intakes (study 2)

\begin{tabular}{|c|c|c|c|}
\hline & \multicolumn{3}{|c|}{ Lead intake } \\
\hline & $\begin{array}{l}\text { Low } \\
(13)^{1} \\
\end{array}$ & $\begin{array}{c}\text { Intermediate } \\
(12)^{1}\end{array}$ & $\begin{array}{c}\text { Moderate } \\
(13)^{1} \\
\end{array}$ \\
\hline $\begin{array}{l}\text { Age (days) } \\
\text { Intake }(\mu \mathrm{g} / \mathrm{kg} / \text { day) }\end{array}$ & 214 & 213 & 235 \\
\hline $\begin{array}{l}\text { Mean } \\
\text { Range }\end{array}$ & $\begin{array}{l}2.83 \\
(0.83-4.31)\end{array}$ & $\begin{array}{l}8.70 \\
(6.31-11.59)\end{array}$ & $(8.60-16.34)$ \\
\hline Urinary excretion $(\mu \mathrm{g} / \mathrm{kg} /$ day $)$ & 0.89 & 1.09 & 0.98 \\
\hline Fecal excretion $(\mu \mathrm{g} / \mathrm{kg} /$ day $)$ & 3.29 & 5.21 & 7.91 \\
\hline Absorption $(\mu \mathrm{g} / \mathrm{kg} /$ day $)$ & -0.46 & 3.49 & 5.37 \\
\hline Retention $(\mu \mathrm{g} / \mathrm{kg} /$ day $)$ & -1.35 & 2.39 & 4.39 \\
\hline
\end{tabular}

${ }_{1}$ Number of studies.

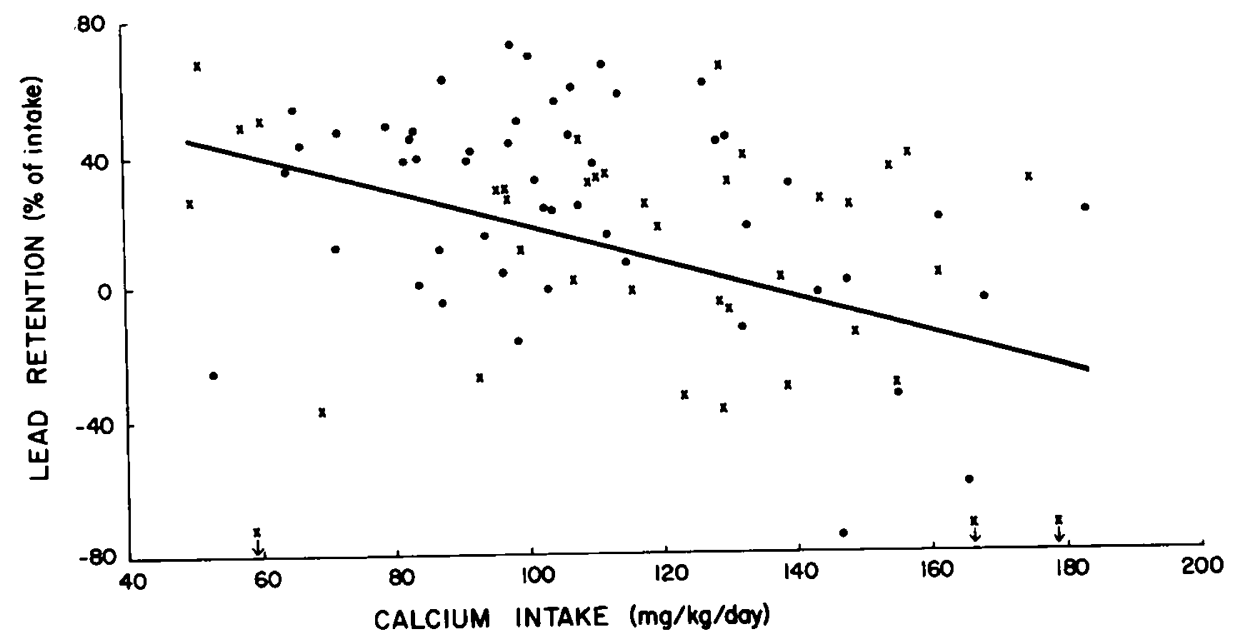

Fig. 4. Lead retention (expressed as percentage of lead intake) in relation to calcium intake. Symbols as in Figure 1. In three Balance studies (arrows) lead retention was (in ascending order of calcium intake) $-245 \%,-167 \%$, and $-374 \%$ of intake. The calculated regression ( $y=$ $-0.547 x+72.57 ; r=-0.284)$ is included. 
tinal tract $8 \mathrm{hr}$ after administration accounted for only $10-17 \%$ of the dose in 16-day to 20-day-old pups but accounted for $85 \%$ in 32-day-old pups.

The data of Kehoe (8) indicate that an average of about $10 \%$ of ingested lead is absorbed by the human adult. This finding has been corroborated more recently by Hursh and Suomela (7) with the use of radioactive isotopes $\left({ }^{212} \mathrm{~Pb}\right)$ and by Rabinowitz et al. (15) using stable isotopes of lead. Few data are available concerning infants and children. Alexander et al. (1) have reported results of 11 balance studies carried out with eight subjects ranging in age from 3 months to 8 years. With intakes averaging $10.6 \mu \mathrm{g} / \mathrm{kg} /$ day (range approximately 5-17 $\mu \mathrm{g} / \mathrm{kg} /$ day), absorption averaged $53 \%$ of intake and retention averaged $18 \%$ of intake.

The present report concerns metabolic balance studies with infants and young children and includes results of two similar studies. Because certain precautions must be taken to maintain intakes of lead below $5 \mu \mathrm{g} / \mathrm{kg} / \mathrm{day}$, it seems likely that most infants and small children not under special study conditions receive intakes greater than this value. We have therefore analzyed separately the data from balance studies with intakes less than $5 \mu \mathrm{g} / \mathrm{kg} /$ day. When intakes of lead exceeded $5 \mu \mathrm{g} / \mathrm{kg} /$ day in the present study, net absorption averaged about $42 \%$ of intake and retention averaged $32 \%$ of intake. Thus, our results are in general agreement with data from animal studies and corroborate to some extent the findings of Alexander $e t$ al. (1) from a small number of studies of infants and children combined. There is little question that infants and young children absorb and retain a greater percentage of ingested lead than has been reported for adults.

The balance technique does not take into account non-dietary intakes and excretions other than those with urine and feces. Although unmeasured losses of lead (e.g., with sweat) are likely to be negligible, intake of lead in inspired air may be substantial. In the present studies lead content of air was monitored and was found to be uniformly low. The estimated intake of lead by inhalation was less than $0.1 \mu \mathrm{g} / \mathrm{kg} / \mathrm{day}$.

It is worth noting that absorption and retention of lead, expressed as percentage of intake, increased significantly with increasing lead intake. These relationships are plausibly explained by relatively high fecal excretion of endogenous lead. The measured apparent retention thus represents a composite of true absorption and endogenous fecal excretion. At low intakes of lead, endogenous fecal excretion may exceed intake and "negative" apparent absorption (and retention) may result. On the other hand, at high intakes, apparent absorption approaches true absorption.

To the extent that the zero intercept of the regression of fecal lead excretion on lead intake provides an estimate of endogenous fecal lead excretion, this value is $1.54 \mu \mathrm{g} / \mathrm{kg} /$ day (Fig. 2). Tracer studies have indicated that endogenous fecal excretion of lead by adult subjects is in the neighborhood of $0.07-0.13$ $\mu \mathrm{g} / \mathrm{kg} /$ day (15). There is, therefore, a suggestion that infants and young children not only absorb lead more efficiently but also excrete it more rapidly than do adults.

An inverse relationship was demonstrated between intake of calcium and absorption and retention of lead (Fig. 4). It should be noted that the bulk of dietary calcium was closely paralleled by intake of phosphorus, of magnesium, and of other (unmeasured) components of milk and formula. Nevertheless, animal studies suggest that calcium is of primary concern.

In the rat, low dietary intake of calcium leads to increased retention $(2,11,12,14,16)$ and toxicity of lead $(12,16)$. Low dietary intake of phosphorus enhances the effect of a low calcium diet, whereas low dietary intake of phosphorus alone has little effect $(2,14)$. Conversely, high dietary intake of calcium diminishes lead absorption (2). Calcium and phosphorus act primarily on intestinal absorption of lead $(2,11,14)$, although low dietary intake of calcium also alters metabolism of lead in bone (14).

\section{CONCLUSION}

The metabolic balance technique was used in this study of infants and children less than 2 years of age to determine net absorption and retention of lead. Milk or formula and commercially prepared foods were fed. With the exception of studies in which intakes of lead were so low that they were considered unlikely to occur under normal circumstances (i.e., less than 5 $\mu \mathrm{g} / \mathrm{kg} /$ day), net absorption averaged $42 \%$ of intake and net retention averaged $32 \%$ of intake. Absorption and retention of lead accounted for greater percentages of intake of lead in this study of infants and young children than has been reported in studies of older subjects. Absorption and retention of lead were inversely correlated with calcium intake.

\section{REFERENCES AND NOTES}

1. Alexander, F. W., Clayton, B. E., and Delves, H. T.: Mineral and tracemetal balances in children receiving normal and synthetic diets. $Q$. J. Med., 43: 89 (1974).

2. Barltrop, D., and Khoo, H. E.: The influence of nutritional factors on lead absorption. Postgrad. Med. J., 51: 795 (1975).

3. Fiorino, J. A., Moffitt, R. A., Woodson, A. E., Gajan, R. J., Huskey, G. E., and Scholz, R. G.: Determination of lead in evaporated milk by atomic absorption spectrophotometry and anodic stripping voltammetry: Collaborative study. J. Ass. Offic. Anal. Chem., 56: 1246 (1973).

4. Fomon, S. J.: Infant Nutrition, Ed. 2, p. 34 (W. B. Saunders Co., Philadelphia, 1974).

5. Fomon, S. J.: Infant Nutrition, Ed. 2, p. 549 (W. B. Saunders Co. Philadelphia, 1974).

6. Forbes, G. B., and Reina, J. C.: Effect of age on gastrointestinal absorption $(\mathrm{Fe}, \mathrm{Sr}, \mathrm{Pb})$ in the rat. J. Nutr., 102: 647 (1972).

7. Hursh, J. B. and Suomela, J.: Absorption of ${ }^{212} \mathrm{~Pb}$ from the gastrointestinal tract of man. Acta Radiol. (Ther.), 7: 108 (1968).

8. Kehoe, R. A.: The metabolism of lead in man in health and disease. II. The metabolism of lead under abnormal conditions. J. Roy. Inst. Pub. Health Hyg., 24: 101 (1961).

9. King, B. G.: Maximum daily intake of lead without excessive body leadburden in children. Amer. J. Dis. Child., 122: 337 (1971).

10. Kostial, K., Simonović, I., and Pišnić, M.: Lead absorption from the intestine in newborn rats. Nature, 233: 564 (1971).

11. Lederer, L. G., and Bing, F. C.: Effect of calcium and phosphorus on retention of lead by growing organism. JAMA, 114: 2457 (1940).

12. Mahaffey, K. R., Goyer, R., and Haseman, J. K.: Dose-response to lead ingestion in rats fed low dietary calcium. J. Lab. Clin. Med., 82: 92 (1973).

13. National Institute for Occupational Safety and Health: NIOSH Manual of Analytical Methods, DHEW Publ. No. (NIOSH) 75-121 (NIOSH, Cincinnati, 1974).

14. Quarterman, J., and Morrison, J. N.: The effects of dietary calcium and phosphorus on the retention and excretion of lead in rats. Brit. J. Nutr., 34: 351 (1975).

15. Rabinowitz, M. B., Wetherill, G. W., and Kopple, J. D.: Kinetic analysis of lead metabolism in healthy humans. J. Clin. Invest., 58 : 260 (1976).

16. Six, K. M., and Goyer, R. A.: Experimental enhancement of lead toxicity by low dietary calcium. J. Lab. Clin. Med., 76: 933 (1970).

17. Analyses in our laboratory indicate that lead content of commercially prepared strained and junior foods marketed for infants is generally less now than at the time of initiation of this study.

18. Dr. K. R. Mahaffey is from the Division of Nutrition, FDA, DHEW, Washington, DC 20204.

19. The assistance in statistical analysis by Peter A. Lachenbruch, Ph.D., is gratefully acknowledged.

20. This research was supported in part by USPHS Grant HD 7578 and in part by FDA RFP 641-4-154.

21. Requests for reprints should be addressed to: Ekhard E. Ziegler, M.D. Department of Pediatrics, University Hospitals, Iowa City, Iowa 52242 (USA).

22. Received for publication January 3, 1977

23. Accepted for publication March 28, 1977. 


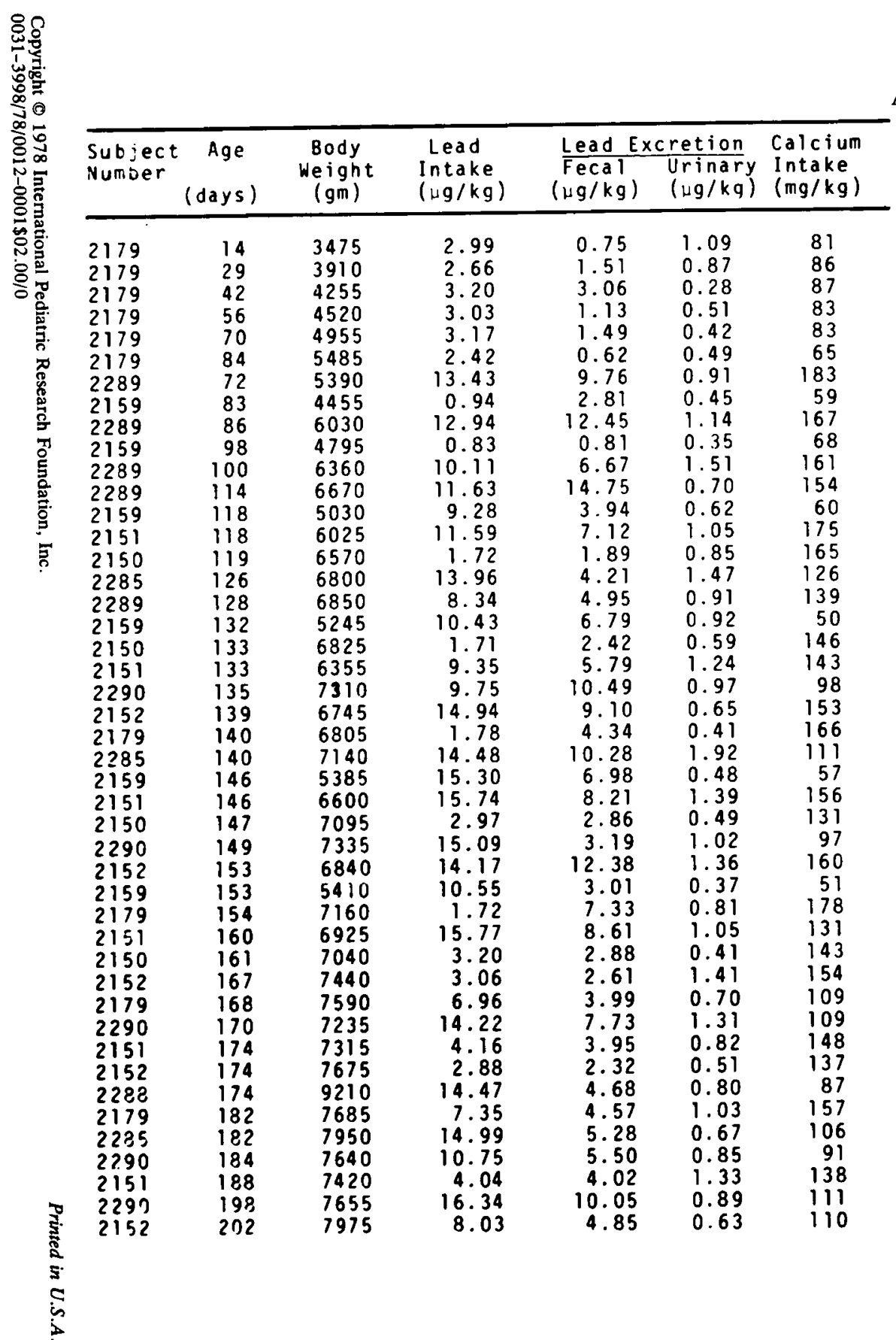

APPENDIX

\begin{tabular}{|c|c|c|c|c|c|c|}
\hline $\begin{array}{l}\text { Subject } \\
\text { Number }\end{array}$ & $\begin{array}{c}\text { Age } \\
\text { (days) }\end{array}$ & $\begin{array}{l}\text { Body } \\
\text { Weight } \\
(g m)\end{array}$ & $\begin{array}{l}\text { Lead } \\
\text { Intake } \\
(\mu g / k g)\end{array}$ & $\begin{array}{l}\text { Lead Ex } \\
\text { Fecal } \\
(\mu \mathrm{g} / \mathrm{kg})\end{array}$ & 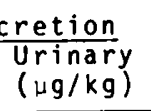 & $\begin{array}{l}\text { Calcium } \\
\text { Intake } \\
\text { (mg/kg) }\end{array}$ \\
\hline $\begin{array}{l}2287 \\
2179 \\
2285 \\
2290 \\
2152 \\
2179 \\
2288 \\
2285 \\
2290 \\
2285 \\
2291 \\
2288 \\
2287 \\
2290 \\
2285 \\
2291 \\
2287 \\
2288 \\
2290 \\
2291 \\
2287 \\
2288 \\
2285 \\
2290\end{array}$ & $\begin{array}{l}202 \\
203 \\
210 \\
212 \\
216 \\
217 \\
216 \\
224 \\
226 \\
238 \\
243 \\
244 \\
245 \\
247 \\
252 \\
257 \\
258 \\
258 \\
268 \\
271 \\
272 \\
272 \\
273 \\
282 \\
289\end{array}$ & $\begin{array}{r}6975 \\
7895 \\
8170 \\
8100 \\
8350 \\
8050 \\
9940 \\
8485 \\
8120 \\
8350 \\
9805 \\
10280 \\
7525 \\
8540 \\
8600 \\
9900 \\
7800 \\
10425 \\
8725 \\
9860 \\
7760 \\
10380 \\
8930 \\
8530 \\
8080\end{array}$ & $\begin{array}{r}13.85 \\
12.94 \\
13.72 \\
16.20 \\
7.84 \\
13.17 \\
12.69 \\
14.13 \\
9.47 \\
16.32 \\
1.87 \\
11.13 \\
17.01 \\
11.43 \\
12.57 \\
3.96 \\
4.56 \\
12.81 \\
3.14 \\
4.23 \\
4.57 \\
11.63 \\
6.91 \\
4.31 \\
14.98\end{array}$ & $\begin{array}{r}12.07 \\
3.34 \\
9.25 \\
8.27 \\
5.25 \\
10.50 \\
6.02 \\
5.34 \\
5.17 \\
3.89 \\
2.28 \\
2.92 \\
5.58 \\
6.80 \\
4.60 \\
3.30 \\
4.10 \\
9.93 \\
3.36 \\
2.36 \\
2.93 \\
6.10 \\
2.81 \\
2.61 \\
10.40\end{array}$ & $\begin{array}{l}1.65 \\
1.30 \\
1.19 \\
0.83 \\
1.22 \\
1.32 \\
0.51 \\
1.91 \\
1.38 \\
1.14 \\
0.07 \\
0.99 \\
5.90 \\
1.87 \\
0.83 \\
0.25 \\
0.50 \\
0.75 \\
0.96 \\
0.40 \\
1.39 \\
0.50 \\
1.02 \\
1.81 \\
1.08\end{array}$ & $\begin{array}{r}147 \\
128 \\
107 \\
107 \\
119 \\
99 \\
79 \\
98 \\
130 \\
100 \\
53 \\
111 \\
103 \\
116 \\
113 \\
71 \\
103 \\
132 \\
128 \\
64 \\
114 \\
97 \\
82 \\
114 \\
102\end{array}$ \\
\hline
\end{tabular}

